\title{
IDENTIFIKASI KARAKTERISTIK BUAH KELAPA SAWIT SIAP PANEN DENGAN METODE LASER SPEKEL IMAGING (LSI)
}

\author{
Neneng Fitrya ${ }^{1)}$, Shabri Putra Wirman ${ }^{2)}$, Wahyuni Fitri ${ }^{3)}$ \\ Program Studi Fisika, Universitas Muhammadiyah Riau, Pekanbaru, Riau, Indonesia \\ email: nenengfitrya@umri.ac.id \\ shabri.pw@umri.ac.id
}

\begin{abstract}
Abstrak
Penanganan panen buah kelapa sawit menjadi suatu kegiatan yang penting dalam meningkatkan mutu CPO (Crude Palm Oil). Untuk mendapatkan CPO yang baik, buah kelapa sawit harus dipanen sesuai waktunya yaitu tepat berada pada tingkat matang. Tingkat kematangan buah sawit dapat di analisa menggunakan metode LSI dan uji fitokimia untuk mengetahui zat antosianin yang terkandung pada setiap tingkat kematangan. Buah sawit yang digunakan adalah jenis marihat dengan tiga tingkat kematangan yaitu mentah, matang, dan terlalu matang. Hasil penelitian metode LSI menunjukkan bahwa semakin bertambahnya tingkat kematangan maka nilai kontras speckle yang dihasilkan akan semakin bertambah besar. Buah mentah memiliki nilai kontras dengan rentang 0,30 sampai 0,43 a.u. Buah matang memiliki nilai kontras dengan rentang 0,35 sampai 0,50 a.u. Buah terlalu matang memiliki nilai kontras dengan rentang 0,40 sampai 0,55 a.u. Bertambahnya nilai kontras dipengaruhi oleh tekstur permukaan buah. Sedangkan ektraksi dari hasil uji fitokimia menyatakan buah mentah memiliki warna hijau,matang berwarna jingga kemerahan, terlalu matang berwarna kuning.Dari kedua uji yang dilakukan maka didapatkan data buah matang memiliki karakteristik warna yang sesuai dengan standar mutu CPO yaitu jingga kemerahan, dengan kontras Speckle dengan rentang 0,35 sampai 0,50 a.u.
\end{abstract}

Kata kunci: Sawit, Laser Speckle Imaging, kadar antosianin, Karakteristik CPO

\begin{abstract}
Handling the harvest of oil palm fruit is an important activity in improving the quality of $\mathrm{CPO}$ (Crude Palm Oil). To get a good CPO, the fruit of oil palm must be harvested according to the time which is right at the mature level. The maturity level of palm fruit can be analyzed using the LSI method and phytochemical test to determine the anthocyanin substances contained at each level of maturity. The palm fruit used is a type of marihat with three levels of maturity, namely raw, ripe, and too ripe. The results of the LSI method research show that the more maturity level the speckle contrast value generated will increase. Raw fruit has a contrast value of 0.30 to 0.43 a.u. Mature fruit has a contrast value with a range of 0.35 to 0.50 a.u. Overcooked fruit has a contrast value of 0.40 to 0.55 a.u. The increase in contrast values is influenced by the texture of the fruit surface. While the extraction from the phytochemical test results stated that the raw fruit has a green color, ripens in a reddishorange color, is too ripe in yellow. From both tests, the ripe fruit data has color characteristics that are in accordance with the CPO quality standard, namely reddish orange. with Speckle contrast with ranges from 0.35 to $0.50 \mathrm{a}$.u.
\end{abstract}

Keywords: Palm, Laser Speckle Imaging, anthocyanin levels, Characteristics of CPO 


\section{PENDAHULUAN}

Indonesia merupakan salah satu negara pengekspor CPO (Crude Palm Oil) terbesar di dunia. Luas total perkebunan kelapa sawit Indonesia menurut Kementerian Pertanian telah mencapai 8 juta hektar pada tahun 2016, dan menjelang tahun 2020 jumlah luas perkebunan dapat bertambah hingga 13 juta hektar (GAPKI,2016). Permasalahan yang sering muncul pada industri kelapa sawit adalah menurunnya kualitas CPO (Crude Palm Oil) pada minyak kelapa sawit. Penyebab menurun nya kualitas CPO Indonesia adalah kandungan asam lemak bebas (ALB) yang tinggi. Penanganan panen buah kelapa sawit menjadi suatu kegiatan yang penting dalam meningkatkan mutu CPO (Crude Palm Oil). Buah kelapa sawit harus dipanen sesuai waktunya, jika terlalu matang maka minyak yang dihasilkan mengandung ALB dalam jumlah tinggi (lebih dari 5\%) sedangkan jika dipanen dalam keadaan belum matang maka tingkat ALB dan rendemen minyak yang dihasilkan akan rendah (Fauzi et al. 2007).

Penentuan tingkat kematangan buah kelapa sawit secara umum ditentukan berdasarkan jumlah brondolan dan warna (Fauzi et al. 2007) . Warna menjadi panduan penting untuk menyatakan kandungan minyak. Antosianin merupakan kandungan pigmen alami yang terdapat pada bagian vakola tumbuhan. Pigmen ini akan memberikan warna merah, biru dan ungu pada buah bergantung keadaan $\mathrm{pH}$. Pada bagian mesocarp buah kelapa sawit mengandung senyawa antosianin. Senyawa antosianin yang terkandung pada buah kelapa sawit akan cenderung menurun seiring dengan bertambahnya tingkat kematangan. Kadar antosianin pada kelapa sawit mentah lebih banyak dari pada buah yang matang. Penentuan tingkat kematangan secara tradisional yang masih mengandalkan tenaga manusia menyebabkan kualitas panen dipengaruhi pengalaman, keahlian, dan pengetahuan. Pemanenan secara tradisonal ini juga bersifat subyektif, lambat dan tidak menyeluruh (Hazir et al. 2012).

Penentuan tingkat kematangan buah kelapa sawit memerlukan cara yang lebih modern dengan dikembangkannya sensor untuk mendeteksi kematangan buah kelapa sawit. Sensor diperlukan karena dalam penggunaannya sensor tidak dipengaruhi oleh faktor eksternal, objektif, secara potensial lebih akurat, dan hasil yang diperoleh sama pada setiap pengukuran. Beberapa sistem sensor untuk menentukan tingkat kematangan buah kelapa sawit sudah banyak diteliti, diantara nya yaitu Metode spektroskopi fluoresensi menghasilkan intensitas fluoresensi tertinggi berada pada tingkat buah kelewat matang sehingga kurang tepat untuk mendeteksi buah tepat matang (Shiddiq et al. 2016). Penelitian selanjutnya mendeteksi kematangan dengan spektrofotometer UV-Vis tetapi penelitian ini membutuhkan reference yang sesuai dengan tingkat pencahayaan yang digunakan (Thoriq. 2016). Selanjutnya juga dilakukan penelitian menggunakan metode LSI namun penelitian ini hanya untuk menganalisa hubungan gray value terhadap tingkat kematangan saja (Minarni, 2016).

Maka pada penelitian ini digunakan metode LSI untuk mengkarakterisasi buah kelapa sawit yang siap panen agar mendapatkan kadar CPO (Crude Palm Oil yang bagus. Metode ini dipilih karena metode ini memiliki kelebihan non dekstruktif dan non invasif (Fitrya, 2013), serta sederhana dalam pengesetan alat karena hanya menggunakan laser, kamera dan display.

\section{METODOLOGI}

Kegiatan penelitian dilakukan di laboratorium Universitas Muhammadiyah Riau Pekanbaru, Penelitian yang dilakukan adalah mengukur kontras speckle pada buah sawit dengan metode LSI. Buah sawit dipilih dari tiga tingkat kematangan, mentah, matang, dan terlalu matang. Masing-masing tingkat 
kematangan diukur kontras speckle nya. Kemudian dilakukan uji kualitatif terhadap buah yang sama untuk melihat zat Antosianin yang terkandung di dalamnya. Diagram alir penelitian diperlihatkan pada Gambar 1.

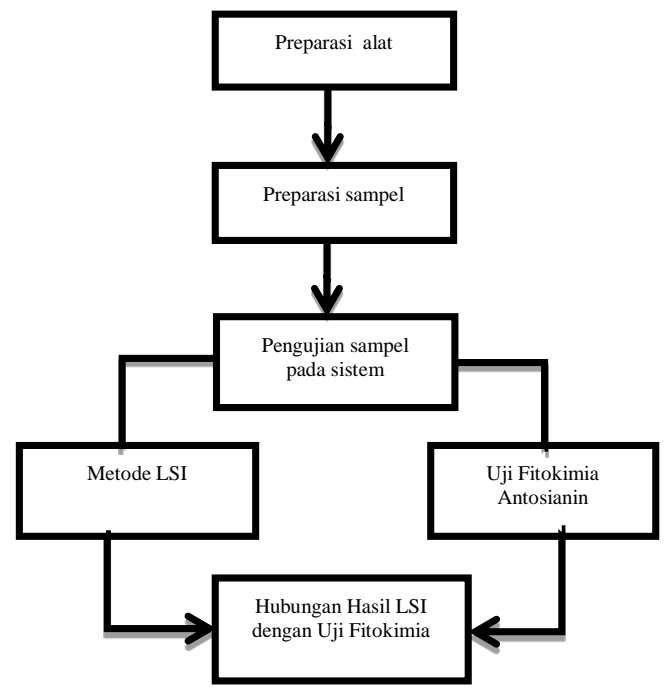

Gambar 1. Diagram Alir Penelitian

\section{HASIL DAN PEMBAHASAN}

Kontras spekel buah sawit didapatkan dari penyinaran laser terhadap buah sawit. Setiap tingkat kematangan diambil data dari 3 (tiga) tandan yang berbeda, masingmasing tandan diambil 5 buah sample dan dilakukan 3 kali pengulangan,sehingga didapatkan 15 data untuk masing-masing tandan.

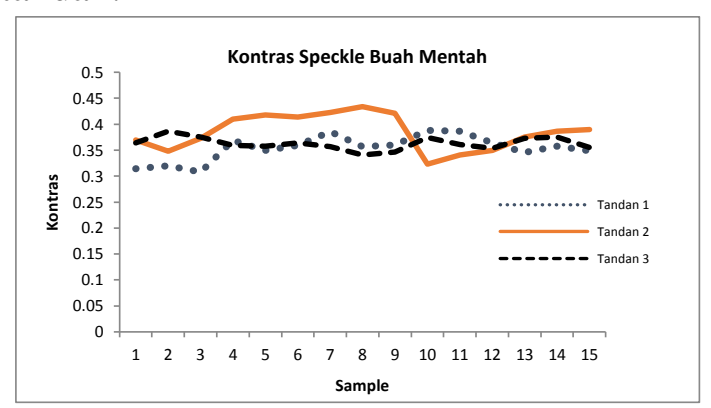

Gambar 2. Kontras Spekle buah mentah

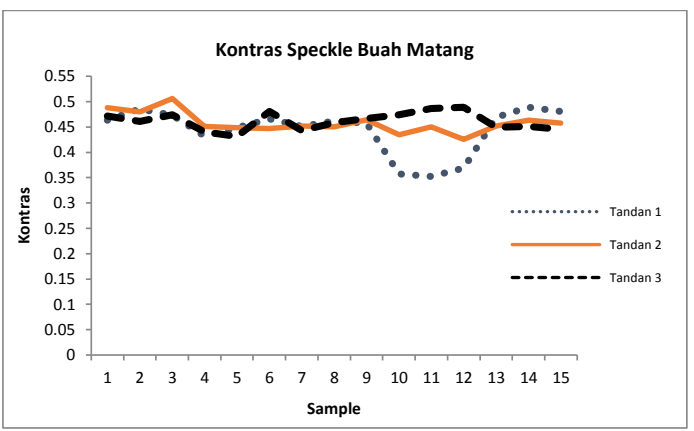

Gambar 3. Kontras Spekle buah matang

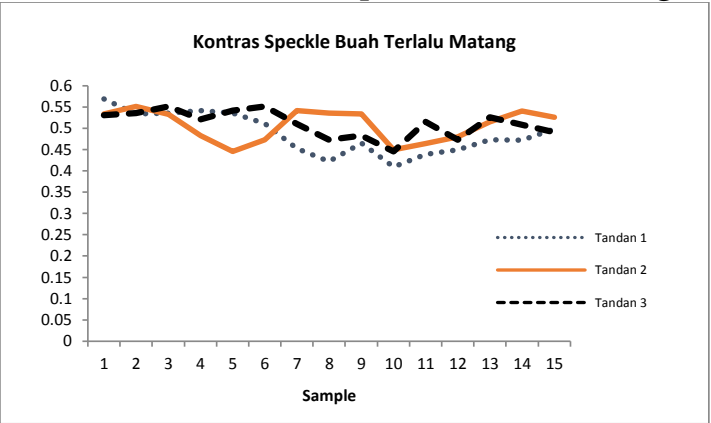

Gambar 4. Kontras Spekle buah terlalu matang

Berdasarkan dari grafik pada gambar diatas, didapat bahwa alat LSI ini mampu mengukur kontras speckle dengan baik. Sehingga dapat membedakan buah mentah,matang, dan terlalu matang. Dari beberapa sampel yang diuji, nilai kontras buah sawit meningkat dengan semakin bertambahnya tingkat kematangan.

Setelah dilakukan pengujian kontras speckle, dilakukan pengujian fitokimia untuk mengetahui zat antosianin yang terdapat didalam buah sawit. Pengujian ini dilakukan secara kualitatif untuk melihat warna pada sample. Uji kulitatif pada sample dapat dilihat pada gambar 4 .

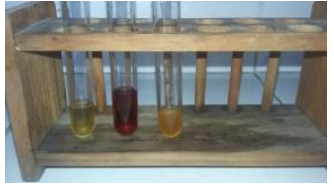

a) Sebelum uji kualitatif

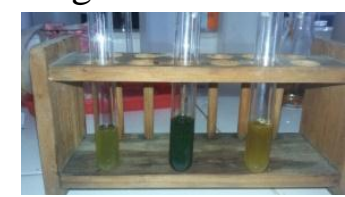

b) Setelah uji kualitatif
Gambar 4. Uji Kualitatif Fitokimia 
Berdasarkan uji fitokimia, ektrak sample buah matang memiliki warna yang sama sesuai dengan standar mutu kualitas $\mathrm{CPO}$, yaitu jingga kemerahan.

\section{PENUTUP}

\section{Kesimpulan}

Setelah dilakukan pengujian nilai kontras spekel pada buah sawit maka dapat diambil beberapa kesimpulan sebagai berikut :

1. Alat LSI ini mampu mengidentifiksi buah kelapa sawit siap panen dengan analisis kontras berdasarkan warna. sehingga didapatkan buah yang baik untuk di proses menjadi CPO sesuai dengan standar mutu

2. Nilai kontras spekel buah matang berkisar antara 0.34637 a.u hingga 0.38449 a.u.

3. Nilai kontras spekel meningkat dengan semakin bertambahnya tingkat kematangan.

\section{Ucapan Terimakasih}

Terima kasih kepada Ristekdikti yang sudah mendanai penelitian ini dan LP2M universitas Muhammadiyah Riau yang sudah membantu kelancaran administrasi yang berhubungan dengan penelitian ini.

\section{DAFTAR PUSTAKA}

Fauzi Y, Widyastuti YE, Satyawibawa I, Hartono R.2007. Kelapa Sawit : Budidaya, Pemanfaatan Hasil dan Limbah, Analisis Usaha dan Pemasaran. Jakarta (ID) : Penebar Swadaya.

Hazir MHM, Sharif ARM, Amirudin MD. 2012. Determination of oil palm fresh fruit bunch ripeness based on flavonoids and anthocyanin content. J. Food Eng.113 (1) : 534-540
Shiddiq, M., Arian, Reza,dkk. 2016. Aplikasi Spektroskopi untuk Asessmen Kematangan Buah Kelapa Sawit. Simposium Fisika Nasional 2016 (SFN XXIX)

Thoriq, A., Sam, Agus. 2016. Kajian Karakteristik Spektrum Tandan Buah Segar (TBS) Kelapa Sawit Berdasarkan Tingkat Kematangan Menggunakan Spektrofotometer UVVis. Jurnal Teknotan (Vol 10. No 1)

Serlahwaty, D. 2007. Kajian Isolasi Karotenoid dari Minyak Sawit Kasar dengan Metode Adsorbsi Menggunakan Penjerap Bahan Pemucat. Tesis. Bogor : Fakultas Teknologi Pertanian, IPB.

Wahyu R., Minarni. 2016. Analisa hubungan Gray Value Spekel dan Tingkat Kematangan Buah Sawit Brondolan Menggunakan Metode LSI. Prosidng SEMIRATA Bidang MIPA 2016. Palembang

Fitrya, N., Sandra., Harmadi. 2013. Analisis Kontras Spekel Menggunakan LSI (Laser Speckle Imaging) Untuk Mendeteksi Formalin Pada Tomat (Lycopersicum Esculentum Mill). Jurnal Fisika dan Aplikasinya, 9(2):80-85.

J.B.Harbone. 2006.Metode Fitokimia penuntun cara modern menganalisis tumbuhan. ITB. Bandung. 